\title{
Bacterial-excreted small volatile molecule 2-aminoacetophenone induces oxidative stress and apoptosis in murine skeletal muscle
}

\author{
ARUNAVA BANDYOPADHAYA ${ }^{1,2}$, CATERINA CONSTANTINOU ${ }^{1,2}$, NIKOLAOS PSYCHOGIOS $^{2,3}$, \\ RYUSUKE UEKI ${ }^{4}$, SHINGO YASUHARA ${ }^{4}$, J.A. JEEVENDRA MARTYN ${ }^{4}$, JULIE WILHELMY $^{5}$, \\ MICHAEL MINDRINOS ${ }^{5}$, LAURENCE G. RAHME ${ }^{1,2}$ and A. ARIA TZIKA ${ }^{2,3}$
}

\begin{abstract}
${ }^{1}$ Department of Surgery, Microbiology and Immunobiology, Harvard Medical School and Molecular Surgery Laboratory, Center for Surgery, Innovation and Bioengineering, Department of Surgery, Massachusetts General and Shriners Burns Hospitals; ${ }^{2}$ NMR Surgical Laboratory, Center for Surgery, Innovation and Bioengineering, Department of Surgery, Massachusetts General and Shriners Burns Hospitals, Harvard Medical School, Boston, MA 02114; ${ }^{3}$ Athinoula A. Martinos Center for Biomedical Imaging,

Department of Radiology, Massachusetts General Hospital and Harvard Medical School, Boston, MA 02129;

${ }^{4}$ Department of Anesthesiology and Critical Care, Massachusetts General Hospital and Harvard Medical School, Boston,

MA 02114; ${ }^{5}$ Department of Biochemistry, Stanford University School of Medicine, Stanford, CA 94305, USA
\end{abstract}

Received July 15, 2015; Accepted November 4, 2015

DOI: $10.3892 / \mathrm{ijmm} .2016 .2487$

\begin{abstract}
Oxidative stress induces mitochondrial dysfunction and facilitates apoptosis, tissue damage or metabolic alterations following infection. We have previously discovered that the Pseudomonas aeruginosa (PA) quorum sensing (QS)-excreted small volatile molecule, 2-aminoacetophenone (2-AA), which is produced in infected human tissue, promotes bacterial phenotypes that favor chronic infection, while also compromising muscle function and dampens the pathogen-induced innate immune response, promoting host tolerance to infection. In this study, murine whole-genome expression data have demonstrated that 2-AA affects the expression of genes involved in reactive oxygen species (ROS) homeostasis, thus producing an oxidative stress signature in skeletal muscle. The results of the present study demonstrated that the expression levels of genes involved in apoptosis signaling pathways were upregulated in the skeletal muscle of 2-AA-treated mice. To confirm the results of our transcriptome analysis, we used a novel high-resolution
\end{abstract}

Correspondence to: Dr A. Aria Tzika, NMR Surgical Laboratory, Center for Surgery, Innovation and Bioengineering, Department of Surgery, Massachusetts General and Shriners Burns Hospitals, Harvard Medical School, Boston, MA 02114, USA

E-mail: atzika@hms.harvard.edu

Dr Laurence G. Rahme, Department of Surgery, Microbiology and Immunobiology, Harvard Medical School and Molecular Surgery Laboratory, Center for Surgery, Innovation and Bioengineering, Department of Surgery, Massachusetts General and Shriners Burns Hospitals, Boston, MA 02114, USA

E-mail: rahme@molbio.mgh.harvard.edu

Key words: Pseudomonas aeruginosa, 2-aminoacetophenone, skeletal muscle, oxidative stress, apoptosis, mitochondria, nuclear magnetic resonance, microarrays, genomics magic-angle-spinning (HRMAS), proton $\left({ }^{1} \mathrm{H}\right)$ nuclear magnetic resonance (NMR) method and observed increased levels of bisallylic methylene fatty acyl protons and vinyl protons, suggesting that 2-AA induces skeletal muscle cell apoptosis. This effect was corroborated by our results demonstrating the downregulation of mitochondrial membrane potential in vivo in response to 2-AA. The findings of the present study indicate that the bacterial infochemical, 2-AA, disrupts mitochondrial functions by inducing oxidative stress and apoptosis signaling and likely promotes skeletal muscle dysfunction, which may favor chronic/persistent infection.

\section{Introduction}

Bacterial pathogens can manipulate the cell survival machinery of the host to establish infection by influencing the host signaling pathways that converge on the mitochondria (1). Mitochondria have been identified as the target of increasing numbers of bacterial products, which are transferred to the cell during infection, a process that often plays a crucial role in microbial pathogenesis (2). Bacterial small molecules have been previously shown to alter mitochondrial function $(3,4)$ and induce apoptosis (5). In addition, the bacterial cell-wall component lipopolysaccharide (LPS) has been shown to promote apoptosis through oxidative stress in host cells (6).

Oxidative stress can be induced by pathogens either directly or indirectly through the induction of host inflammatory mediators $(7,8)$. A major cause of oxidative stress is reactive oxygen species (ROS) generation in cells, which are a by-product of energy production in the mitochondria $(9,10)$. The increased generation of ROS and changes in the redox homeostasis have been described in the context of a number of microbial infections (11-13), and the failure to maintain an appropriate redox balance contributes to microbial pathogenesis through alterations in mitochondrial functions and the induction of apoptosis $(14,15)$. 
Apoptosis plays a critical role in tissue homeostasis and regulates multiple physiological processes, including immune responses, infection and reduces inflammation-mediated tissue injury by removing damaged cells (16). Apoptosis is initiated through several processes: i) by the activation/ stimulation of death receptors, including Fas, tumor necrosis factor (TNF)- $\alpha$ receptor I, and TNF-related apoptosis-inducing ligand receptors 1 and 2 (17); ii) by caspase activation that is independent of death receptors (18); iii) or by mitochondrial factors, such as apoptosis-inducing factor (AIF), which are independent of caspase activation (18). Increased apoptotic signals in the alveolar epithelium are related to the presence of chronic infections in patients with cystic fibrosis (CF) (19).

The opportunistic pathogen Pseudomonas aeruginosa (PA) thrives in patients with $\mathrm{CF}$, burns and/or immunocompromised individuals $(20,21)$ and utilizes cell-to-cell communication systems, termed quorum sensing (QS) (22) to establish acute and chronic infection (23-27). QS relies on the presence of smallexcreted molecules termed herein 'infochemicals', to coordinate the concomitant expression of multiple virulence genes (28). It has been reported that PA QS-excreted infochemicals modulate the host innate immune response $(29,30)$. The PA-excreted infochemical, 2-aminoacetophenone (2-AA), promotes phenotypic changes in the pathogen that favor chronic infection $(26,31)$ and dampens pathogen-induced inflammation that in turn favors host tolerance to infection (30). We have recently demonstrated that 2-AA reduces energy metabolism, promotes mitochondrial dysfunction and impairs muscle functions, which may further favor chronic and persistent infections (32) and potentially induces oxidative stress in skeletal muscle.

In this study, we used whole-genome expression and ex vivo nuclear magnetic resonance (NMR) to examine the effects of 2-AA on the oxidative response and apoptosis in skeletal muscle. NMR spectroscopy can be used to determine mitochondrial dysfunction and assess metabolic alterations in muscle $(33,34)$. Furthermore, in vivo microscopy can be used to determine the reduction in mitochondrial membrane potential, which is a signature of mitochondrial dysfunction and induces apoptosis. The results of the present study demonstrated that the inhibition of genes involved in oxidative homeostasis resulted in the accumulation of ROS and increased apoptosis in skeletal muscle. Thus, 2-AA promotes mitochondrial dysfunction and compromises normal skeletal muscle functions (32) through the induction of oxidative stress and apoptosis, thus promoting pathogenicity.

\section{Materials and methods}

Ethics statement. This study was carried out in strict accordance with the recommendations of the Guide for the Care and Use of Laboratory Animals of the National Institutes of Health. The study protocol was approved by the Committee on the Ethics of Animal Experiments at Massachusetts General Hospital (Boston, USA; permit nos. 2006N000093 and 2013N000034). All procedures were performed on mice which had been anaesthetized with a combination of xylazine $(12.5 \mathrm{mg} / \mathrm{kg})$ and ketamine $(125$ $\mathrm{mg} / \mathrm{kg}$ ), and every effort was made to minimize suffering.

Experimental animals. Six-week-old male CD1 mice weighing approximately 20-25 g were purchased from Charles River Laboratory (Boston, MA, USA). Twenty-eight mice were used in this study. The animals were kept in a controlled environment with a regular light-dark cycle (lights on from 8:00 to 20:00) with an ambient temperature of $22 \pm 1^{\circ} \mathrm{C}$, and were allowed free access to food and water. The mice received an intraperitoneal (IP) injection of 2-AA ( $6.75 \mathrm{mg} / \mathrm{kg})$, and mouse skeletal muscle was analyzed 4 days post-AA treatment. Ex vivo proton nuclear magnetic resonance ( ${ }^{\mathrm{l}} \mathrm{H}$ NMR) spectroscopy was performed on intact gastrocnemius muscle samples.

High-resolution magic-angle-spinning (HRMAS) ${ }^{l} H$ NMR spectroscopy of intact skeletal muscle tissue. At 4 days post-2-AA treatment, eight 2-AA-treated and eight untreated animals (that served as a control) were analyzed using HRMAS ${ }^{1} \mathrm{H}$ NMR spectroscopy. The left gastrocnemius muscle was harvested, immediately frozen in liquid nitrogen, and stored at approximately $-80^{\circ} \mathrm{C}$. The same muscle from untreated animals served as a control. HRMAS ${ }^{1} \mathrm{H}$ NMR spectroscopic analysis of muscle tissue was performed on a Bruker Bio-Spin Avance NMR spectrometer (proton frequency at $600.13 \mathrm{MHz}$, with an 89 -mm vertical bore) using a 4-mm triple resonance $\left({ }^{1} \mathrm{H},{ }^{13} \mathrm{C},{ }^{2} \mathrm{H}\right)$ HRMAS probe (Bruker, Billerica, MA, USA). The temperature was maintained at $4^{\circ} \mathrm{C}$ with a BTO-2000 thermocouple unit in combination with a magic angle spinning (MAS) pneumatic unit (Bruker). The MAS speed was stabilized at $4.0 \pm 0.001 \mathrm{kHz}$ using a MAS speed controller. The ${ }^{1} \mathrm{H}$ NMR spectra were acquired for all samples using a Carr-Purcell-Meiboom-Gill (CPMG) spin echo pulse sequence $\left[90^{\circ}-\left(\tau--180^{\circ}-\tau-\right)_{n}\right.$-acquisition], with an inter-pulse delay $(\tau-)$ of $250 \mu \mathrm{sec}$. Hard $90^{\circ}\left(8 \tau\right.$-s) and $180^{\circ}(16 \tau$-s) were employed. As previously described (32), the relaxation delay was set to $2 \mathrm{sec}$, and spectra were collected both with and without water suppression. The transverse relaxation time $\left(\mathrm{T}_{2}\right)$ was measured using the same CPMG pulse sequence by varying $n$ from 0 to 520. Free induction decay (FID) signals were acquired with $8 \mathrm{k}$ points, a $600 \mathrm{msec}$ acquisition time, 8 dummy scans and 128 scans. HRMAS ${ }^{1} \mathrm{H}$ NMR spectra were analyzed using the MestRe-C NMR software package (Mestrelab Research, Santiago de Compostela, Spain; www.mestrec.com). FIDs were zero-filled to 16k points and apodized with exponential multiplication $(1 \mathrm{~Hz})$ prior to Fourier transformation. The spectra were then manually phased and corrected for baseline broad features (Whittaker smoother, smooth factor 10,000). The Levenberg-Marquardt algorithm was used to least-squares-fit a model of mixed Gaussian/Lorentzian functions to the data. The $\left(\mathrm{CH}_{2}\right)_{\mathrm{n}-2}$ peak at $1.32 \mathrm{ppm}$ was selected for the quantification of intramyocellular lipids (IMCLs). As the sample was spun at a magic angle, and the sample was much smaller $(25 \mu \mathrm{l})$ and more homogeneous (reduced bulk magnetic susceptibility effects) than the typical voxel size $(1 \mathrm{ml})$ of in vivo ${ }^{1} \mathrm{H}$ MRS, no chemical shift difference was observed between IMCL and extramyocellular lipids (EMCL). The small size of the muscle biopsies and the fact that the samples were collected from the most myocellular part of the muscle suggest that the main contribution to the $\left(\mathrm{CH}_{2}\right)_{\mathrm{n}-2}$ peak was made by IMCL lipids.

Absolute quantification of metabolites from 1-DCPMG spectra. Resonance intensities were measured for $-\mathrm{CH}_{3}$ protons of the trimethylsilyl-propionic-2,2,3,3-d4 acid (TSP) and compared to the resonance intensities measured for metabolites. The peak intensities of most of the metabolites, as well as of TSP, were 
calculated from the intensity of the respective resonance $(\mathrm{X})$ measured from the $\mathrm{T}_{2}$-filtered HRMAS ${ }^{1} \mathrm{H}$ MR spectrum. The calculated peak intensities were then corrected for $\mathrm{T}_{2}$ relaxation, using $\operatorname{Ic}(X)=\operatorname{Ir}(X){ }^{*} \exp \left(T_{\mathrm{CPMG}} / \mathrm{T}_{2}(X)\right) / \mathrm{n}$, where $\operatorname{Ir}(X)$ is the measured intensity, $\mathrm{T}_{\mathrm{CPMG}}$ is the CPMG echo time, and $n$ is the number of protons in the functional group and corresponds to the resonance of the metabolite. In accordance with the 'external standard' technique employed (35), metabolite concentrations were quantified relative to the absolute concentration $(\mu \mathrm{mol})$ of the respective metabolite $[\mathrm{M}]=\mathrm{Ic}(\mathrm{M}) /\left(\mathrm{Ic}_{\mathrm{TSP}}(\mathrm{M}){ }^{*} \mathrm{wt}\right)$, where wt is the weight of the sample in grams.

Statistical analysis of HRMAS ${ }^{l} \mathrm{H} N M R$ spectroscopy data. Data are reported as the means \pm standard errors of the mean. Between-groups comparison was performed using analysis of variance with Bonferroni correction for multiple comparisons. A corrected p-value of $<0.0125$ was deemed to indicate a statistically significant difference. A comparison between measurements was performed in each group with a t-test (twotailed, $\mathrm{p}<0.0125)$. All analyses were performed using SPSS software (SPSS version 12; SPSS Inc., Chicago, IL, USA).

Extraction of RNA samples. As previously described (32), the left gastrocnemius muscle was harvested at 4 days post 2-AA treatment $(n=3)$, to determine the changes in gene expression in whole muscle. The muscle specimens of the anesthetized animals were excised and immediately immersed in $1 \mathrm{ml} \mathrm{TRIzol} \mathrm{(Gibco-BRL,}$ Invitrogen, Carlsbad, CA, USA) for RNA extraction. Each muscle specimen was homogenized for $60 \mathrm{sec}$ with a Brinkmann Polytron 3000 homogenizer prior to total RNA extraction. Chloroform $(200 \mu \mathrm{l})$ was added to the homogenized muscle and mixed by inverting the tube for $15 \mathrm{sec}$. Following centrifugation at $12,000 \mathrm{x} \mathrm{g}$ for $15 \mathrm{~min}$, the upper aqueous phase was collected and precipitated by the addition of $500 \mu \mathrm{l}$ isopropanol. Further centrifugation at $12,000 \times \mathrm{g}$ for $10 \mathrm{~min}$ separated the RNA pellet, which was then washed with $500 \mu 1$ of $70 \%$ ethanol and centrifuged at 7,500 $\mathrm{xg}$ for $5 \mathrm{~min}$ prior to air drying. The pellet was resuspended in $100 \mu$ diethylpyrocarbonate (DEPC) water. An RNeasy kit (Qiagen, Germantown, MA, USA) was used to purify the RNA according to the manufacturer's instructions. The purified RNA was quantified by UV absorbance at 260 and $280 \mathrm{~nm}$, and stored at $-70^{\circ} \mathrm{C}$ for DNA microarray analysis.

Microarray hybridization. As previously described (32), biotinylated cRNA was generated with $10 \mu \mathrm{g}$ of total cellular RNA according to the protocol outlined by Affymetrix Inc. (Santa Clara, CA, USA). cRNA was hybridized onto MOE430A oligonucleotide arrays (Affymetrix), stained, washed and scanned according to the Affymetrix protocol.

Genomic data analysis. As previously described (32), data of the scanned image files hybridized with probes from RNA extracted from the gastrocnemius muscle isolated at the specified times from the 2-AA-treated and untreated control mice $(n=3)$ were converted to cell intensity files (CEL files) with the Microarray suite 5.0 (MAS; Affymetrix). The data were scaled to a target intensity of 500, and all possible pairwise array comparisons of the replicates to normal control mice were performed using a MAS 5.0 change call algorithm. Probe sets that had a signal value difference $>100$ and for which one



Figure 1. 2-Aminoacetophenone (2-AA) affects reactive oxygen species (ROS) metabolism and the response to oxidative stress in murine skeletal muscle. Black bars indicate the number of downregulated genes; gray bars indicate the number of upregulated genes in the skeletal muscle of mice 4 days after 2-AA treatment versus the control mice (left vertical axis). The negative $\log 10$ of p-values represented by gray triangles are indicated in the right vertical axis.

of the two samples being compared was not termed 'absent', were scored as differentially modulated when i) the number of change calls in the same direction were at least 3,4 and 6 , when the number of comparisons were 4, 6 and 9, respectively; and ii) the other comparisons were unaltered. Based on the ratios of 100 genes determined to be invariant in most conditions tested (Affymetrix), an additional constraint of a minimum ratio of 1.65 was applied to control the known false positives at 5\%. The microarray data are available at http://www.ncbi. nlm.nih.gov/geo/info/linking.html and the accession number is GSE43779. Gene Ontology (GO) analysis was performed using GeneSpring GX software (version 11) by Agilent Technologies (Santa Clara, CA, USA).

In vivo microscopic measurement of mitochondrial membrane potential. Following 4 days of treatment with 2-AA $(6.75 \mathrm{mg} /$ $\mathrm{kg})$, the 2-AA treated mice and the untreated controls $(\mathrm{n}=3)$ were anesthetized and underwent in vivo microscopic observation as previously described $(36,37)$ with modifications. Briefly, sternocleidomastoid muscles were exposed and stained with $40 \mathrm{nM} 3,3$ '-dihexyloxacarbocyanine iodide $\left(\mathrm{DiOC}_{6}\right)$ and $1 \mu \mathrm{M}$ CellTracker Orange (Invitrogen) for $30 \mathrm{~min}$. After washing, the fluorescence intensity of $\mathrm{DiOC}_{6}$, which reflects mitochondrial membrane potential, was recorded. The consistency of dye accessibility and image caption was confirmed by internal control staining with CellTracker Orange. The captured images were analyzed and their fluorescence intensity was analyzed by densitometry with ImageJ software (http://imagej.nih.gov/ij/).

\section{Results}

2-AA treatment affects ROS homeostasis and production and the response to oxidative stress. Using microarray analysis, we identified a subset of differentially expressed genes that have functional annotations of oxidative stress and mitochondrial function. Several genes involved in ROS homeostasis (group A) and in the response to oxidative stress (group B) were downregulated (Fig. 1 and Table I). 
Table I. Differential expression of genes involved in ROS homeostasis and oxidative stress in mouse skeletal muscle 4 days following an injection of 2-AA.

\begin{tabular}{|c|c|c|c|c|}
\hline GenBank & Gene name & Fold change & p-value & GO Biological process \\
\hline \multicolumn{5}{|l|}{ Group A } \\
\hline NM_009127 & Stearoyl-coenzyme A desaturase 1 & $(-) 4.3$ & 0.024 & Oxygen and ROS metabolism \\
\hline AF173681 & Thioredoxin interacting protein & $(-) 4.4$ & 0.038 & Oxygen and ROS metabolism \\
\hline NM_009804 & Catalase & $(-) 8.6$ & 0.013 & Oxygen and ROS metabolism \\
\hline NM_020569 & $\begin{array}{l}\text { Parkinson disease (autosomal recessive, } \\
\text { early onset) } 7\end{array}$ & $(-) 2.3$ & 0.029 & Oxygen and ROS metabolism \\
\hline NM_011435 & Superoxide dismutase 3 , extracellular & $(-) 4.5$ & 0.018 & Oxygen and ROS metabolism \\
\hline NM_021356 & $\begin{array}{l}\text { Growth factor receptor bound protein } \\
\text { 2-associated protein } 1\end{array}$ & $(-) 2.4$ & 0.028 & Oxygen and ROS metabolism \\
\hline NM_011563 & Peroxiredoxin 2 & $(-) 2.1$ & 0.016 & Oxygen and ROS metabolism \\
\hline NM_001111320 & Isocitrate dehydrogenase $1\left(\mathrm{NADP}^{+}\right)$, soluble & $(-) 4.2$ & 0.041 & Oxygen and ROS metabolism \\
\hline NM_013603 & Metallothionein 3 & $(+) 2.8$ & 0.023 & Oxygen and ROS metabolism \\
\hline NM_010497 & Isocitrate dehydrogenase $1\left(\mathrm{NADP}^{+}\right)$, soluble & $(-) 3.1$ & 0.023 & Oxygen and ROS metabolism \\
\hline NM_018881 & Flavin containing monooxygenase 2 & $(-) 4.6$ & 0.022 & Oxygen and ROS metabolism \\
\hline NM_023505 & Glutaredoxin 2 (thioltransferase) & $(-) 2$ & 0.027 & Oxygen and ROS metabolism \\
\hline ВC019664 & Glutathione peroxidase 8 (putative) & $(-) 4$ & 0.005 & Oxygen and ROS metabolism \\
\hline NM_013711 & Thioredoxin reductase 2 & $(-) 3.5$ & 0.025 & Oxygen and ROS metabolism \\
\hline AF412308 & Thioredoxin reductase 2 & $(-) 2.4$ & 0.009 & Oxygen and ROS metabolism \\
\hline NM_027629 & Phosphoglucomutase 2-like 1 & $(+) 9.8$ & 0.023 & Oxygen and ROS metabolism \\
\hline NM_013671 & Superoxide dismutase 2 , mitochondrial & $(-) 5.8$ & 0.008 & Oxygen and ROS metabolism \\
\hline M14222 & Cathepsin B & $(-) 2.5$ & 0.028 & Oxygen and ROS metabolism \\
\hline NM_008161 & Glutathione peroxidase 3 & $(-) 3.7$ & 0.005 & Oxygen and ROS metabolism \\
\hline AF274027 & $\begin{array}{l}\text { Phospholipid hydroperoxide glutathione } \\
\text { peroxidase }\end{array}$ & $(-) 3$ & 0.020 & Oxygen and ROS metabolism \\
\hline NM_018881 & Flavin containing monooxygenase 2 & $(-) 5.3$ & 0.007 & Oxygen and ROS metabolism \\
\hline XM_006508205 & Phosphoglucomutase 2-like 1 (predicted) & $(+) 5.1$ & 0.013 & Oxygen and ROS metabolism \\
\hline \multicolumn{5}{|l|}{ Group B } \\
\hline AF173681 & Thioredoxin interacting protein & $(-) 4.4$ & 0.038 & Response to oxidative stress \\
\hline NM_009804 & Catalase & $(-) 8.6$ & 0.013 & Response to oxidative stress \\
\hline NM_020569 & $\begin{array}{l}\text { Parkinson disease (autosomal recessive, } \\
\text { early onset) } 7\end{array}$ & $(-) 2.3$ & 0.029 & Response to oxidative stress \\
\hline NM_021356 & $\begin{array}{l}\text { Growth factor receptor bound protein } 2 \text { - } \\
\text { associated protein } 1\end{array}$ & $(-) 2.4$ & 0.028 & Response to oxidative stress \\
\hline NM_011563 & Peroxiredoxin 2 & $(-) 2.1$ & 0.016 & Response to oxidative stress \\
\hline NM_001111320 & Isocitrate dehydrogenase $1\left(\mathrm{NADP}^{+}\right)$, soluble & $(-) 4.2$ & 0.041 & Response to oxidative stress \\
\hline NM_010497 & Isocitrate dehydrogenase $1\left(\mathrm{NADP}^{+}\right)$, soluble & $(-) 3.1$ & 0.023 & Response to oxidative stress \\
\hline NM_023505 & Glutaredoxin 2 (thioltransferase) & $(-) 2$ & 0.027 & Response to oxidative stress \\
\hline ВC019664 & Glutathione peroxidase 8 (putative) & $(-) 4$ & 0.005 & Response to oxidative stress \\
\hline NM_013711 & Thioredoxin reductase 2 & $(-) 3.5$ & 0.025 & Response to oxidative stress \\
\hline AF412308 & Thioredoxin reductase 2 & $(-) 2.4$ & 0.009 & Response to oxidative stress \\
\hline NM_027629 & Phosphoglucomutase 2-like 1 & $(+) 9.8$ & 0.023 & Response to oxidative stress \\
\hline NM_013671 & Superoxide dismutase 2 , mitochondrial & $(-) 5.8$ & 0.008 & Response to oxidative stress \\
\hline M14222 & Cathepsin B & $(-) 2.5$ & 0.028 & Response to oxidative stress \\
\hline NM_008161 & Glutathione peroxidase 3 & $(-) 3.7$ & 0.005 & Response to oxidative stress \\
\hline AF274027 & Glutathione peroxidase 4 & $(-) 3$ & 0.020 & Response to oxidative stress \\
\hline XM_006508205 & Phosphoglucomutase 2-like 1 (predicted) & $(+) 5.1$ & 0.013 & Response to oxidative stress \\
\hline
\end{tabular}

Values represent the relative expression intensity of the 2-aminoacetophenone (2-AA)-treated versus the untreated control mice. Annotations for biological processes are from the Gene Ontology Consortium (http://geneontology.org/). +, Upregulation of genes compared with muscle from normal untreated mice; -, downregulation of genes compared with muscle from normal untreated mice. GenBank and gene names can be searched at http://www.ncbi.nlm.nih.gov/gene/. ROS, reactive oxygen species. 


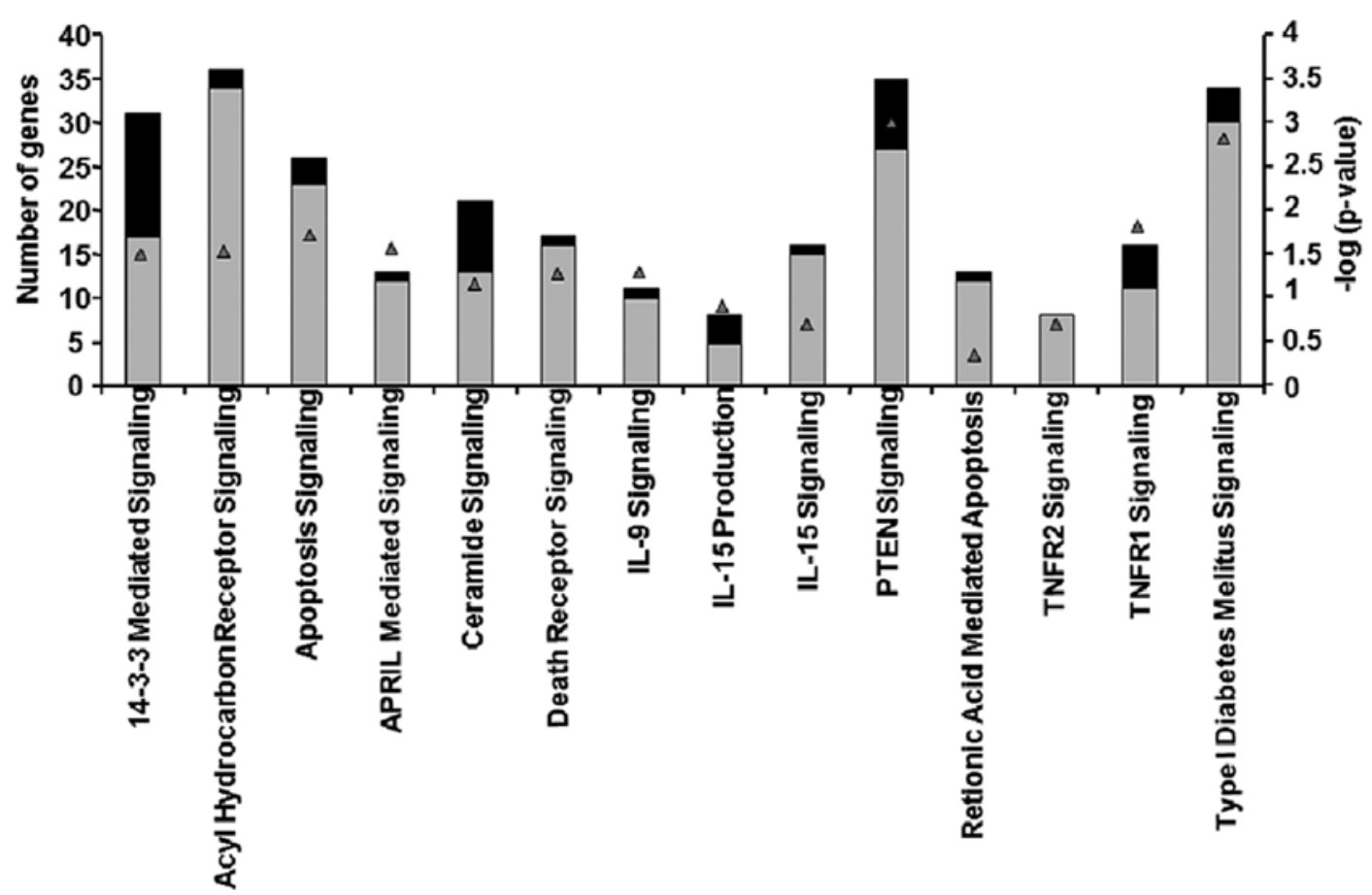

Figure 2. 2-Aminoacetophenone (2-AA) affects genes involved in the apoptosis pathway in murine skeletal muscle. Black bars indicate the number of downregulated genes; gray bars indicate the number of upregulated genes in the skeletal muscle of mice 4 days after 2-AA treatment versus the control mice (left vertical axis). The negative $\log 10$ of p-values represented by gray triangles are indicated in the right vertical axis.

Differential expression of genes involved in the apoptosis signaling pathway in skeletal muscle of 2-AA-treated mouse. The microarray data presented in Table II and Fig. 2 demonstrated that certain genes, which had been identified as functioning in apoptosis via annotation by Gene Ontology Consortium and Ingenuity, were differentially expressed. Almost $97 \%$ of the genes involved in apoptosis signaling were upregulated in mouse skeletal muscle after 4 days of treatment with 2-AA (Table II and Fig. 2). For example, the TNF receptor superfamily member $1 \alpha$ gene exhibited an increased expression. This gene encodes a major TNF- $\alpha$ receptor that activates nuclear factor- $\kappa \mathrm{B}(\mathrm{NF}-\kappa \mathrm{B})$, mediates apoptosis and regulates inflammation (17). In addition, genes encoding B-cell lymphoma (Bcl)-2, which function downstream of the TNF- $\alpha$ receptor in apoptosis signaling (38), exhibited an increased expression. Specifically, the upregulation of Bcl-2-like 13 (apoptosis facilitator), which is a member of Bcl-2 family of proteins, promotes apoptosis by blocking caspase inhibitors (39). The upregulation of PERP (p53 apoptosis effector), a p53 transcriptional target, promotes apoptosis (40). Fas apoptotic inhibitory molecules which confer resistance to Fas-induced apoptosis (41), were also downregulated following 2-AA treatment. The increased expression of growth arrest-specific 2 (Gas2) genes may activate apoptosis (42) in murine muscle of 2-AA-treated mice.

Several other genes were also upregulated, including heat shock proteins, lectins and AIF, the death associated protein. In addition, we noted that mitochondrial-dependent apoptosis genes which encode cytochrome $c$ and caspases exhibited an increased expression.

${ }^{1}$ H NMR detects muscle lipid accumulation following 2-AA treatment. ${ }^{1} \mathrm{H}$ NMR spectroscopy has been used to explore metabolic changes $(33,34,43)$. The accumulation of mobile lipids is associated with mitochondrial dysfunction, oxidative stress and apoptosis $(44,45)$. As shown in Fig. 3 and Table III, the results of NMR spectroscopy demonstrated that most lipid peaks were consistently increased in the skeletal muscle samples from the 2-AA-treated mice compared to the control mice.

The stack plot presented in Fig. 3 shows typical examples of proton HRMAS ${ }^{1} \mathrm{H}$ MRS CPMG spectra from skeletal muscle samples. This plot contains spectra of the control and 2-AA-treated animals sacrificed 4 days post-2-AA-treatment, with the spectra scaled to the phosphocreatine and creatine 3.02-ppm peak. Resonance signals are due to residual water (4.7-4.8 ppm); terminal methyl (0.8-1.0 ppm); acyl chain methylene (1.1-1.5 ppm); $\alpha$ - and $\beta$-methylene (2.0-2.5 ppm) and olefinic protons (5.4 ppm) of lipids; N-methyl protons of phosphocreatine and creatine (3.0 ppm); and $\mathrm{N}$-trimethyl protons of betaines $(3.2 \mathrm{ppm})$, which correspond to taurine and cholinecontaining compounds. The phospholipids at $3.2 \mathrm{ppm}$ appear unaffected by 2-AA treatment and remain stable, along with other peaks between 3 and $4 \mathrm{ppm}$. The results from quantitative analysis of these high-resolution ex vivo HRMAS ${ }^{1} \mathrm{H}$ MRS measurements are shown in Table III. Bisallylic methylene fatty acyl protons at $2.8 \mathrm{ppm}$ correspond to polyunsaturated fatty acids (PUFAs), which accumulate due to apoptosis. Vinyl proton accumulation at $5.4 \mathrm{ppm}$, including protons from ceramide and possibly other sphingolipids suggests apoptosis.

Downregulation of mitochondrial membrane potential in skeletal muscle from 2-AA-treated mice. Mitochondrial membrane potential is considered a biomarker of oxidative stress and apoptosis $(46,47)$. In vivo fluorescence microscopy with 
Table II. Differential expression of genes involved in the apoptosis signaling pathway in mouse skeletal muscle samples following 4 days of treatment with 2-AA.

\begin{tabular}{|c|c|c|c|}
\hline GenBank & Gene name & Fold change & p-value \\
\hline NM_030711 & Endoplasmic reticulum aminopeptidase 1 (Erap1) & 2.264 & 0.0158 \\
\hline NM_134131 & Tumor necrosis factor, $\alpha$-induced protein 8 & 3.863 & 0.0183 \\
\hline NM_023517 & Tumor necrosis factor (ligand) superfamily, member 13 (Tnfsf13) & 3.293 & 0.0061 \\
\hline NM_009396 & Tumor necrosis factor- $\alpha$-induced protein & 5.796 & 0.00082 \\
\hline NM_009425 & Tumor necrosis factor (ligand) superfamily, member 10 & 3.398 & 0.0226 \\
\hline NM_011614 & Tumor necrosis factor (ligand) superfamily, member 12 (Tnfsf12) & 2.735 & 0.03 \\
\hline NM_022310 & Heat shock $70 \mathrm{kDa}$ protein 5 (glucose-regulated protein) & 4.146 & 0.0118 \\
\hline AF250139 & Small stress protein-like protein (HSP22) & 6.137 & 0.0106 \\
\hline NM_010481 & Heat shock protein $9 \mathrm{~A}$ & 3.462 & 0.0107 \\
\hline NM_013560 & Heat shock protein 1 & 3.248 & 0.0146 \\
\hline NM_013559 & Heat shock protein 110 & -3.95 & 0.0367 \\
\hline U03561 & Heat shock protein HSP 27 internal deletion variant $b$ & 4.008 & 0.025 \\
\hline NM_010477 & Heat shock protein 1 (chaperonin) & 2.915 & 9.33E-05 \\
\hline NM_010480 & Heat shock protein $90, \alpha$ (cytosolic), class A member 1 (Hsp90aa1) & -2.63 & 0.0484 \\
\hline NM_001163434 & Heat shock $70 \mathrm{kDa}$ protein 5 (glucose-regulated protein) & 3.076 & 0.00638 \\
\hline NM_001164708 & Heat shock protein 2 & 5.374 & 0.0412 \\
\hline NM_013868 & Heat shock protein family, member 7 (cardiovascular) & 6.046 & 0.0427 \\
\hline NM_011020 & Heat shock $70 \mathrm{kDa}$ protein 4 like & -2.43 & 0.0368 \\
\hline NM_008303 & Heat shock protein 1 (chaperonin 10$)$ & 3.313 & 0.034 \\
\hline M12573 & Heat shock protein $1 \mathrm{~B}$ & 3.49 & 3.49 \\
\hline XM_006500766 & Heat shock $70 \mathrm{kDa}$ protein 4 like & -5.49 & 0.0266 \\
\hline NM_028306 & Heat shock protein $12 \mathrm{~B}$ & 8.802 & 0.0479 \\
\hline NM_009883 & CCAAT/enhancer binding protein $(\mathrm{C} / \mathrm{EBP}) \beta$ & 4.288 & 0.0215 \\
\hline NM_009884 & CCAAT/enhancer binding protein $(\mathrm{C} / \mathrm{EBP}) \gamma$ & 2.352 & 0.0479 \\
\hline NM_010499 & Immediate early response 2 & 2.68 & 0.0161 \\
\hline NM_008495 & Lectin, galactose binding, soluble 1 & 4.588 & 0.0481 \\
\hline NM_001145953 & Lectin, galactose binding, soluble 3 & 2.464 & 0.0162 \\
\hline NM_001199043 & Lectin, galactose binding, soluble 8 & 2.019 & 0.00659 \\
\hline NM_010708 & Lectin, galactose binding, soluble 9 & 4.736 & 0.0464 \\
\hline NM_019738 & Nuclear protein 1 & 2.299 & 0.0239 \\
\hline NM_134141 & Cytokine induced apoptosis inhibitor 1 & 2.295 & 0.0222 \\
\hline NM_022032 & PERP, TP53 apoptosis effector & 12.73 & 0.0252 \\
\hline BC023121 & CASP8 and FADD-like apoptosis regulator & 2.91 & 0.0075 \\
\hline NM_001177552 & Bifunctional apoptosis regulator & 2.006 & 0.0414 \\
\hline NM_054056 & PRKC, apoptosis, WT1, regulator & 3.307 & 0.03 \\
\hline NM_001038658 & Fas apoptotic inhibitory molecule 2 & -2.39 & 0.0493 \\
\hline NM_153516 & BCL2-like 13 (apoptosis facilitator) & 2.796 & 0.0205 \\
\hline NM_001039194 & $\begin{array}{l}\text { Apoptosis-inducing factor (AIF)-like mitochondrion-associated } \\
\text { inducer of death }\end{array}$ & 2.033 & 0.0445 \\
\hline NM_007609 & Caspase 4 , apoptosis-related cysteine peptidase (Casp4), mRNA & 3.446 & 0.00128 \\
\hline NM_001042558 & Apoptotic peptidase activating factor 1 & 2.701 & 0.016 \\
\hline NM_001165935 & Apoptosis, caspase activation inhibitor & 2.149 & 0.0206 \\
\hline NM_001038658 & Fas apoptotic inhibitory molecule 2 & -22.32 & 0.00627 \\
\hline ВC003292 & Programmed cell death 8 & 3.129 & 0.0449 \\
\hline ВC026823 & Programmed cell death 6 interacting protein & 2.436 & 0.00988 \\
\hline NM_001164677 & Programmed cell death 6 interacting protein & 4.606 & 0.000958 \\
\hline NM_019746 & Programmed cell death 5 & 2.834 & 0.0486 \\
\hline ВC024876 & Death-associated protein & 3.706 & 0.0196 \\
\hline NM_007566 & Baculoviral IAP repeat-containing 6 & 2.586 & 0.00413 \\
\hline NM_001301639 & $\mathrm{X}$-linked inhibitor of apoptosis (Xiap), transcript variant 1 & 2.44 & 0.0415 \\
\hline
\end{tabular}


Table II. Continued.

\begin{tabular}{|c|c|c|c|}
\hline GenBank & Gene name & Fold change & p-value \\
\hline NM_053207 & EGL nine homolog 1 (C. elegans) & 2.658 & 0.026 \\
\hline AK017394 & Growth arrest specific 7 & -34.15 & 0.000771 \\
\hline NM_026832 & Cell growth regulator with ring finger domain 1 & 3.016 & 0.0446 \\
\hline NM_001109657 & Growth arrest-specific 7-cb protein (Gas7-cb) & -32.15 & 0.0113 \\
\hline NM_008655 & Growth arrest and DNA-damage-inducible $45 \beta$ & 3.297 & 0.0366 \\
\hline NM_001033331 & Growth arrest-specific 2 like 3 & 4.312 & 0.0324 \\
\hline NM_001277080 & Growth arrest-specific 7-cb protein (Gas7-cb) & -19.88 & 0.0303 \\
\hline AF037370 & Cytochrome $c$ oxidase, subunit VIIa 1 & 10.56 & 0.0445 \\
\hline NM_007808 & Cytochrome c, somatic & 3.344 & 0.0391 \\
\hline NM_007747 & Cytochrome $c$ oxidase, subunit Va & 3.291 & 0.035 \\
\hline NM_009941 & Cytochrome $c$ oxidase subunit IV isoform 1 & 2.642 & 0.0202 \\
\hline NM_007751 & Cytochrome $c$ oxidase, subunit VIIIb & 5.591 & 0.0399 \\
\hline AA190297 & Cytochrome $c$ oxidase, subunit VIIc & 2.104 & 0.0296 \\
\hline NM_025628 & Cytochrome $c$ oxidase, subunit VIb polypeptide 1 & 2.015 & 0.0144 \\
\hline NM_024226 & Reticulon 4 & -7.51 & 0.0255 \\
\hline BF455257 & Reticulon 1 & -29.85 & 0.00175 \\
\hline BM246564 & Phosphodiesterase 4B, cAMP specific & 2.161 & 0.0488 \\
\hline NM_009811 & Caspase 6 & 3.503 & 0.0107 \\
\hline NM_007611 & Caspase 7 & 3.837 & 0.00433 \\
\hline NM_001163138 & Caspase recruitment domain family, member 6 & 3.344 & 0.00725 \\
\hline NM_007611 & Caspase 7 & 4.957 & 0.0082 \\
\hline ВC008152 & Caspase 1 & 4.165 & 0.0361 \\
\hline NM_001171007 & $\begin{array}{l}\text { Nucleotide-binding oligomerization domain containing } 1 \text { (Nod1)/ } \\
\text { Caspase recruitment domain } 4\end{array}$ & 2.35 & 0.0266 \\
\hline
\end{tabular}

+ , Upregulation of genes compared with normal untreated muscle; -, downregulation of genes compared with normal untreated muscle. 2-AA, 2-aminoacetophenone. GenBank and gene names can be found at http://www.ncbi.nlm.nih.gov/gene/.

$\mathrm{DiOC}_{6}$ indicated that 2-AA treatment reduced skeletal muscle mitochondrial membrane potential by $41 \%$ compared to the untreated control group ( $<<0.05$; Fig. 4). The fact that internal control staining with CellTracker Orange revealed equivalent staining between the two groups confirmed that the difference observed in membrane potential was not due to staining issues (i.e., dye accessibility or fluctuation in image capturing).

\section{Discussion}

In the present study, we demonstrate that 2-AA, a QS-regulated requisite for PA pathogenesis and a diagnostically important bacterial molecule, induces oxidative stress in skeletal muscle, disrupts the defense against oxidative stress, reduces mitochondrial membrane potential and enhances apoptotic signaling (Fig. 5). The reduced expression of genes involved in ROS metabolism and in the oxidative stress response may be responsible for the accumulation of ROS in skeletal muscle. ROS toxicity may lead to mitochondrial dysfunction, possibly via damage to mitochondrial DNA (mtDNA) and reduced mitochondrial potential. Our findings also suggest a reduction in the oxidative stress response as a potential mechanism through which 2-AA modulates the apoptotic pathway, and suggest candidate targets through which to limit oxidative stress and apoptosis in patients with infection.

The principal finding of the present study was the effect of 2-AA on ROS production and the antioxidant status homeostasis in skeletal muscle, which correlates with the induction of apoptosis. Normally, increased ROS induce antioxidant defenses and prevent damage to mitochondrial macromolecules; in the absence of such defenses, oxidative damage ensues. In addition, the oxidative stress caused by increased ROS production results in apoptosis (8). Based on the findings of this study, we suggest that 2-AA interferes with ROS detoxification resulting in oxidative damage to mitochondrial macromolecules, possibly including mtDNA. ROS initiate damage to nucleic acids, proteins and lipids (10). Since mitochondrial DNA (mtDNA) is located closer to the site of ROS generation, lacks protective histones, and has more limited base excision repair mechanisms than the nucleus, it is more vulnerable to oxidative damage than nuclear DNA (nDNA) $(48,49)$.

Another major finding of this study concurs with oxidative stress and is accompanied by mitochondrial dysfunction. In a recent study, we demonstrated that peroxisomal proliferator activator receptor (PPAR) $-\gamma$ and PPAR- $\gamma$ co-activator (PGC)1 expression was downregulated by $2-\mathrm{AA}$ (32). PGC1 is hypoth- 
Table III. Results of ${ }^{1} \mathrm{H}$ NMR HRMAS experiments performed on gastrocnemius muscle specimens from 2-AA-treated mice versus control mice.

\begin{tabular}{lllcrr}
\hline $\begin{array}{l}\text { Chemical shift } \\
\text { PPM }\end{array}$ & $\begin{array}{c}\text { Chemical } \\
\text { group }\end{array}$ & Control & 4 days post-2-AA & $\begin{array}{c}\text { Percent } \\
\text { change }\end{array}$ & p-value \\
\hline 2.8 & $=\mathrm{CH}-\mathrm{CH} 2-\mathrm{CH}=$ & $0.012 \pm 0.004^{\mathrm{a}}$ & $0.040 \pm 0.007$ & +233 & $0.0075^{\text {b }}$ \\
5.4 & $\mathrm{CH}=\mathrm{CH}-$ & $0.041 \pm 0.015$ & $0.226 \pm 0.058$ & +451 & 0.0233 \\
\hline
\end{tabular}

${ }^{\mathrm{a}}$ Values $\left(\mu \mathrm{mol} / \mathrm{g}\right.$ muscle) are represented as the means \pm standard error of the means from 8 samples/group; ${ }^{\mathrm{b}} \mathrm{p}$-value for comparisons between 2-aminoacetophenone (2-AA)-treated and normal mice obtained with the Student's t-test; + , indicates increase. ${ }^{1} \mathrm{H}$ NMR, proton nuclear magnetic resonance; HRMAS, high-resolution magic-angle-spinning.

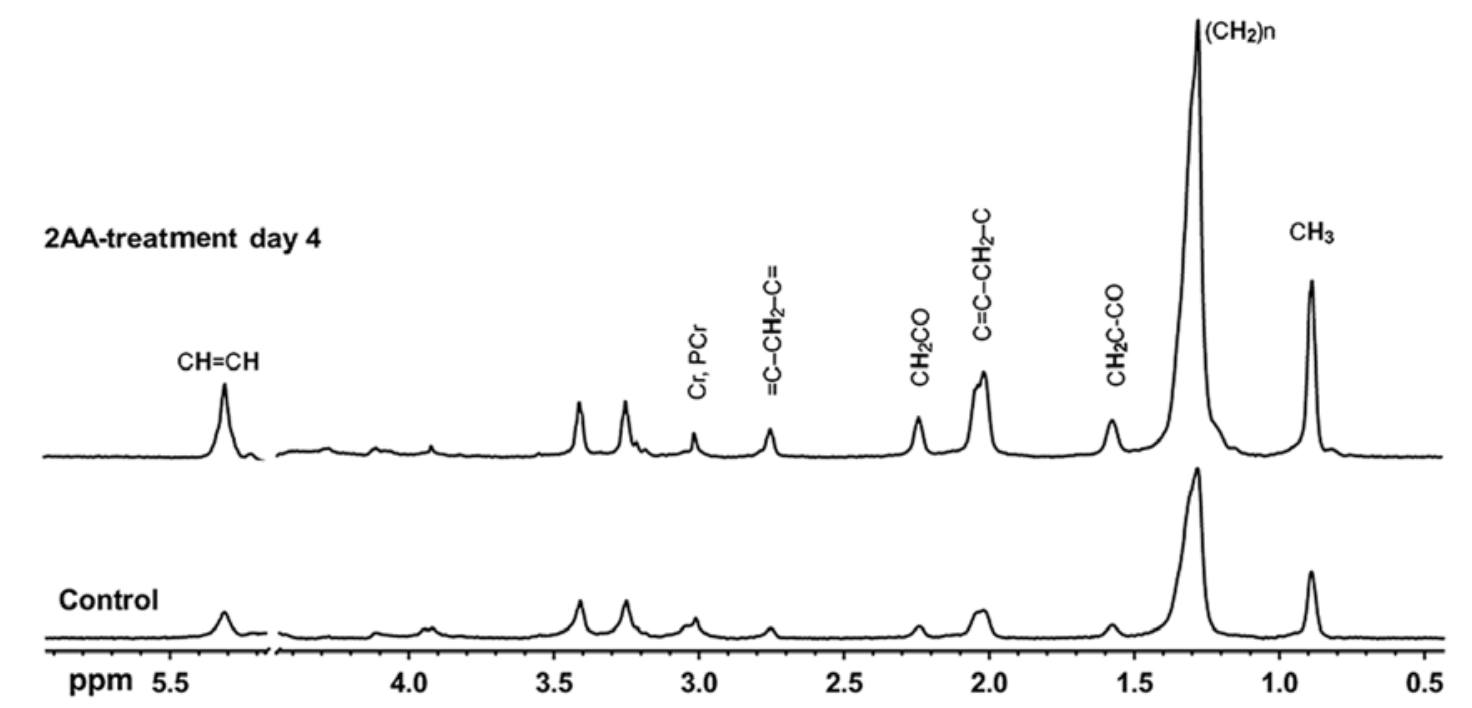

Figure 3. Nuclear magnetic resonance (NMR) spectra from ${ }^{1} \mathrm{H}-\mathrm{NMR}$ high-resolution magic-angle-spinning (HRMAS) experiments performed on the gastrocnemius skeletal muscle specimens of mice. The spectra were acquired from normal and 2-aminoacetophenone (2-AA)-treated mice at 4 days post-2-AA treatment and scaled to the phosphocreatine and creatine peak (3.02 ppm). The lipid peak at $1.3 \mathrm{ppm}$ is attributed to methylene protons of intra-myocellular triglyceride acyl chains, primarily due to intramyocellular lipids (IMCLs). Resonance signals are due to residual water (4.7-4.8 ppm); terminal methyl (0.8-1.0 ppm); acyl chain methylene (1.1-1.5 ppm); $\alpha$ - and $\beta$ - methylene (2.0-2.5 ppm) and olefinic protons (5.4 ppm) of lipids; N-methyl protons of phosphocreatine and creatine $(3.0 \mathrm{ppm})$; and $\mathrm{N}$-trimethyl protons of betaines $(3.2 \mathrm{ppm})$, which correspond to taurine and choline-containing compounds. Bisallylic methylene fatty acyl protons at $2.8 \mathrm{ppm}$ correspond to polyunsaturated fatty acids (PUFAs), which accumulate due to apoptosis. Vinyl proton accumulation at $5.4 \mathrm{ppm}$, including protons from ceramide and possibly other sphingolipids suggests apoptosis.

esized to play a central role in regulating energy homeostasis and metabolism (50). Therefore, the observed downregulation of genes involved in oxidative phosphorylation (32) and also in ROS detoxification by 2-AA may be explained by the effect of 2-AA on PGC1 (32). As a result of this dysregulation, the balance of detoxification and ROS generation may be shifted towards ROS accumulation. To this end, this study complies with the notion that certain components of the ROS scavenging pathway are linked by PGC1 to mitochondrial oxidative phosphorylation, apparently preventing cells from maintaining the normal redox status in response to a change in ROS production (51).

In this study, the expression of genes which encode proteins with pro- or anti-apoptotic functions was altered in response to 2-AA treatment (Fig. 2 and Table II); however, their exact regulatory role remains unclear. These data may reflect a heterogeneous mRNA population which is due to a direct effect of 2-AA on the underlying superficial layers of the hind limb muscle, and the asynchronous state of apoptotic muscle cells. Nonetheless, our data demonstrated that apoptotic pathways are activated in muscle from 2-AA-treated mice, which further demonstrates a link between the dysregulation of fatty acid oxidation (32), lipid accumulation (32) and apoptosis. Furthermore, the mitochondrial release of pro-apoptotic proteins, such as cytochrome $c$ is promoted by the formation of specific channels in the outer membrane of the mitochondria by pro-apoptotic Bcl-2 family members (39). Once released, cytochrome $c$ triggers the activation of caspases, which in turn regulates the apoptotic process (18) and has been suggested to induce contractile dysfunction (52). The orderly process of apoptosis is energy dependent and, consequently, damage to the mitochondria to the point that they can no longer produce ATP can easily shift to apoptosis (53). The core apoptotic pathway and cellular energy metabolism maintain an important inter-relationship between apoptosis and mitochondrial function (54), which is modulated by 2-AA.

In the present study, we noted that lipids accumulated in muscle tissue following 2-AA treatment, as assessed by 



Figure 4. 2-Aminoacetophenone (2-AA) reduces mitochondrial membrane potential in murine skeletal muscle. Mitochondrial membrane potential was analyzed by in vivo microscopy. (A) In vivo fluorescence microscopic images are shown both for 2-AA-treated (left column) and untreated (right column) groups. Green fluorescence (top panel) from 3,3'-dihexyloxacarbocyanine iodide ( $\mathrm{DiOC}_{6}$ ) staining represents mitochondrial membrane potential, and red signal (bottom panel) from CellTracker Orange staining is for internal control staining. The white scale bar at the bottom represents $200 \mu \mathrm{m}$. (B) The average fluorescence signal was quantified by densitometry and shown as a bar graph with the standard error of the means. 2-AA-treated group showed a significantly decreased signal as compared to the controls. ${ }^{*} \mathrm{p}<0.05$, according to Student's t-test.



Figure 5. Representative schematic diagram showing that 2-aminoacetophenone (2-AA) induces oxidative stress and apoptosis in skeletal muscle. 2-AA induces oxidative stress by generating reactive oxygen species (ROS). The oxidative damage and ROS reduce mitochondrial membrane potential $(\Delta \Psi)$, and release Bcl-2 and cytochrome $c$, which promotes apoptosis. Lipid accumulation following 2-AA treatment potentially generates apoptotic signals in the cells $(58,59)$. The red arrows denote the induction of the cellular components.

${ }^{1} \mathrm{H}$ NMR. The lipid peak at 1.3 ppm in Fig. 3 has been attributed to methylene protons of intra-myocellular triglyceride acyl chains, primarily due to IMCLs (55), which suggests that the increase in NMR-visible lipids at $1.4 \mathrm{ppm}$ after 2-AA treatment is primarily due to increased quantifiable IMCL. This conclusion is further supported by the results of previous studies on humans $(56,57)$. Conversely, EMCLs which may contribute to the $1.4 \mathrm{ppm}$ peak are relatively metabolically inert and serve as a long-term energy storage depot with slow turnover. EMCLs are therefore unlikely to correspond to the lipids observed in this study, which rapidly accumulated post-2-AA treatment.

The accumulation of lipids is associated with apoptosis $(58,59)$; and the present study demonstrates that 2-AA induced apoptosis-related gene expression (Table II) and increased the lipid profile (Fig. 3) in skeletal muscle, which could be linked. The increase in bisallylic methylene fatty acyl protons at $2.8 \mathrm{ppm}$ is in accordance with the data of Hakumäki et al (60), which suggested that these protons corre- spond to PUFAs, and PUFA accumulation follows apoptosis. In addition, our data demonstrate vinyl proton accumulation at $5.4 \mathrm{ppm}$, including protons from ceramide and possibly other sphingolipids, such as sphingosine. Indeed, ceramide and sphingolipids are known to be involved in apoptosis (61). These increased signals suggest that ceramide, a product of sphingolipid metabolism, contributes to 2-AA-mediated apoptosis. Ceramide and sphingolipids, in particular, have been implicated as second messengers for apoptotic stimuli, including TNF- $\alpha$ (62), Fas ligand (63), ionizing radiation (64), heat shock (65) and oxidative stress (66).

The loss of mitochondrial membrane potential leads to the activation of apoptotic signals in several tissues, including skeletal muscle (67). When apoptotic signals reach the mitochondria, membrane permeability transition occurs, involving voltage-dependent anion channels (VDAC), adenine nucleotide translocase (ANT) and translocator protein (TSPO) (68). Damaged mitochondria are known to release apoptosis-inducing 
molecules, including cytochrome $c$, endonuclease G, AIF and Smac/Diablo and HtrA2/Omi $(36,67)$. Other research has also demonstrated that uncoupled mitochondria become a major source for cellular ROS production (69). The data from our in vivo microscopic analysis support the molecular biological observation that the increase in apoptosis and ROS accumulation occurred in skeletal muscle of mice treated with 2-AA.

PA and 2-AA in the lungs of chronically infected patients with $\mathrm{CF}$ are considered pathogenomic (70,71). Patients with CF often develop skeletal muscle wasting due to inadequate antioxidant defenses which cannot cope with the elevated oxidative stress $(72,73)$, and increased apoptosis is observed in airway cells of patients with CF $(19,74)$. The characteristic loss of muscle mass, coupled with a decrease in strength, force output and alteration in oxidative stress, has previously been shown to be associated with apoptotic pathways and is an underlying mechanism of the pathogenesis of chronic disease $(75,76)$. Oxidative stress and ROS accumulation can alter muscle gene expression, causing protein loss that consequently diminishes muscle mass or function (75). Nuclear receptor subfamily 2 , group F, member 2 (NR2F2), a member of the steroid thyroid hormone superfamily of nuclear receptors, which is required for skeletal muscle development (77) and appears to be involved in the regulation of oxidative stress (78), was also downregulated (1.65-fold, $\mathrm{p}<0.0094)$ in the skeletal muscle of 2-AA-treated mice (data not shown). This suggests that 2-AA-mediated muscle dysfunction (32) may be the result of increased oxidative stress and apoptosis.

Mitochondrial dysfunction may interact with oxidative stress (14), lipid accumulation (59), apoptosis (79) and innate immune response (80). 2-AA abridges energy production and mitochondrial function in skeletal muscle, which may favor chronic diseases $(32,81)$ and chronic infection (30). Recently, we demonstrated that 2-AA acts as an immunomodulatory signal (30) and likely affects insulin resistance associated with a molecular signature of mitochondrial dysfunction (32) that increases the ability of the host to live with the pathogen, enabling tolerance to infection and a long-term bacterial presence leading to bacterial persistence (30). Therefore, 2-AA-mediated oxidative stress and the activation of apoptotic signals may serve to eliminate key immune cells or evade host defenses (1) and further contribute to a long-term bacterial presence (30). The results of the present study are consistent with previous data of other chronic infections, including Escherichia coli (82), tuberculosis (83), Helicobacter pylori (84) and patients chronically infected with CF (85).

In conclusion, our results from transcriptome analysis and NMR spectroscopy provide strong evidence that the altered NMR-visible lipid profile is related to apoptosis which is induced by oxidative stress in response to the bacterial infochemical, 2-AA. 2-AA-mediated oxidative stress leads to mitochondrial dysfunction, which results in host metabolic dysfunction and apoptosis, and such a dysregulation in host metabolism can promote chronic/persistent disease state (30). Lipid accumulation may reflect apoptosis, rather than providing a direct measure of mitochondrial dysfunction. Since apoptosis and cellular energy metabolism are the two major determinants of cell survival, NMR-visible lipids may serve as biomarkers to monitor therapies for muscle wasting following bacterial infection, as well as other disease states. To this end, our results provide insight into the response of skeletal muscle to the PA-excreted small molecule, 2-AA, and point to novel therapeutic possibilities in targeting antioxidant pathways to reduce oxidative stress and apoptosis in skeletal muscle.

\section{Acknowledgements}

This study was supported in part by Shriner's Hospital for Children research grants (nos. 87100 and 85200), and Basic Research Award, W81XWH-10-DMRDP-BRA from US Army Medical Research Acquisition Act of US Department of Defense, Congressionally Directed Medical Research Programs (CDMRP), Defense Medical Research and Development Program (DMRDP) to Laurence G. Rahme, and by a Center grant of the National Institutes of Health (NIH) to the Stanford Genome Technology Cente, as well as by NIH grant AI105902. We acknowledge Dr Damien Maura at the Massachusetts General Hospital and Harvard Medical School for his insightful comments on the manuscript.

\section{References}

1. Rudel T, Kepp O and Kozjak-Pavlovic V: Interactions between bacterial pathogens and mitochondrial cell death pathways. Nat Rev Microbiol 8: 693-705, 2010.

2. Jiang $\mathbf{J H}$, Tong $\mathbf{J}$ and Gabriel $\mathrm{K}$ : Hijacking mitochondria: bacterial toxins that modulate mitochondrial function. IUBMB Life 64: 397-401, 2012.

3. Trumpower BL: Cytochrome bcl complexes of microorganisms. Microbiol Rev 54: 101-129, 1990.

4. Van Ark G and Berden JA: Binding of HQNO to beef-heart submitochondrial particles. Biochim Biophys Acta 459: 119-127, 1977.

5. Schwarzer C, Fu Z, Shuai S, Babbar S, Zhao G, Li C and Machen TE: Pseudomonas aeruginosa homoserine lactone triggers apoptosis and Bak/Bax-independent release of mitochondrial cytochrome $\mathrm{C}$ in fibroblasts. Cell Microbiol 16: 1094-1104, 2014.

6. Raza H, John A and Shafarin J: NAC attenuates LPS-induced toxicity in aspirin-sensitized mouse macrophages via suppression of oxidative stress and mitochondrial dysfunction. PLoS One 9: e103379, 2014.

7. Valyi-Nagy T and Dermody TS: Role of oxidative damage in the pathogenesis of viral infections of the nervous system. Histol Histopathol 20: 957-967, 2005.

8. Pohanka M: Role of oxidative stress in infectious diseases. A review. Folia Microbiol (Praha) 58: 503-513, 2013.

9. Murphy MP: How mitochondria produce reactive oxygen species. Biochem J 417: 1-13, 2009.

10. Schieber M and Chandel NS: ROS function in redox signaling and oxidative stress. Curr Biol 24: R453-R462, 2014.

11. Ding SZ, Minohara Y, Fan XJ, Wang J, Reyes VE, Patel J, Dirden-Kramer B, Boldogh I, Ernst PB and Crowe SE: Helicobacter pylori infection induces oxidative stress and programmed cell death in human gastric epithelial cells. Infect Immun 75: 4030-4039, 2007.

12. Strengert M, Jennings R, Davanture S, Hayes P, Gabriel G and Knaus UG: Mucosal reactive oxygen species are required for antiviral response: role of Duox in influenza a virus infection. Antioxid Redox Signal 20: 2695-2709, 2014.

13. Paracha UZ, Fatima K, Alqahtani M, Chaudhary A, Abuzenadah A, Damanhouri G and Qadri I: Oxidative stress and hepatitis C virus. Virol J 10: 251, 2013.

14. Pieczenik SR and Neustadt J: Mitochondrial dysfunction and molecular pathways of disease. Exp Mol Pathol 83: 84-92, 2007.

15. Garofalo RP, Kolli D and Casola A: Respiratory syncytial virus infection: mechanisms of redox control and novel therapeutic opportunities. Antioxid Redox Signal 18: 186-217, 2013.

16. Ashida H, Mimuro H, Ogawa M, Kobayashi T, Sanada T, Kim $M$ and Sasakawa C: Cell death and infection: a doubleedged sword for host and pathogen survival. J Cell Biol 195: 931-942, 2011. 
17. Guicciardi ME and Gores GJ: Life and death by death receptors. FASEB J 23: 1625-1637, 2009.

18. Madeo F, Carmona-Gutierrez D, Ring J, Büttner S, Eisenberg T and Kroemer G: Caspase-dependent and caspase-independent cell death pathways in yeast. Biochem Biophys Res Commun 382: 227-231, 2009

19. Galli F, Battistoni A, Gambari R, Pompella A, Bragonzi A, Pilolli F, Iuliano L, Piroddi M, Dechecchi MC and Cabrini G Working Group on Inflammation in Cystic Fibrosis: oxidative stress and antioxidant therapy in cystic fibrosis. Biochim Biophys Acta 1822: 690-713, 2012.

20. Navon-Venezia S, Ben-Ami R and Carmeli Y: Update on Pseudomonas aeruginosa and Acinetobacter baumanni infections in the healthcare setting. Curr Opin Infect Dis 18: 306-313, 2005

21. Kerr KG and Snelling AM: Pseudomonas aeruginosa: a formidable and ever-present adversary. J Hosp Infect 73: 338-344, 2009

22. Jimenez PN, Koch G, Thompson JA, Xavier KB, Cool RH and Quax WJ: The multiple signaling systems regulating virulence in Pseudomonas aeruginosa. Microbiol Mol Biol Rev 76: 46-65, 2012.

23. Déziel E, Gopalan S, Tampakaki AP, Lépine F, Padfield KE, Saucier M, Xiao G and Rahme LG: The contribution of MvfR to Pseudomonas aeruginosa pathogenesis and quorum sensing circuitry regulation: multiple quorum sensing-regulated genes are modulated without affecting lasRI, rhIRI or the production of N-acyl-L-homoserine lactones. Mol Microbiol 55: 998-1014, 2005.

24. Xiao G, Déziel E, He J, Lépine F, Lesic B, Castonguay MH, Milot S, Tampakaki AP, Stachel SE and Rahme LG: MvfR, a key Pseudomonas aeruginosa pathogenicity LTTR-class regulatory protein, has dual ligands. Mol Microbiol 62: 1689-1699, 2006.

25. Parker CT and Sperandio V: Cell-to-cell signalling during pathogenesis. Cell Microbiol 11: 363-369, 2009.

26. Kesarwani M, Hazan R, He J, Que YA, Apidianakis Y, Lesic B, Xiao G, Dekimpe V, Milot S, Deziel E, et al: A quorum sensing regulated small volatile molecule reduces acute virulence and promotes chronic infection phenotypes. PLoS Pathog 7 : e1002192, 2011.

27. Zhou L, Slamti L, Nielsen-LeRoux C, Lereclus D and Raymond B: The social biology of quorum sensing in a naturalistic host pathogen system. Curr Biol 24: 2417-2422, 2014.

28. Ng WL and Bassler BL: Bacterial quorum-sensing network architectures. Annu Rev Genet 43: 197-222, 2009.

29. Rumbaugh KP and Kaufmann GF: Exploitation of host signaling pathways by microbial quorum sensing signals. Curr Opin Microbiol 15: 162-168, 2012.

30. Bandyopadhaya A, Kesarwani M, Que YA, He J, Padfield K, Tompkins $\mathrm{R}$ and Rahme LG: The quorum sensing volatile molecule 2-amino acetophenon modulates host immune responses in a manner that promotes life with unwanted guests. PLoS Pathog 8: e1003024, 2012.

31. Que YA, Hazan R, Strobel B, Maura D, He J, Kesarwani M, Panopoulos P, Tsurumi A, Giddey M, Wilhelmy J, et al: A quorum sensing small volatile molecule promotes antibiotic tolerance in bacteria. PLoS One 8: e80140, 2013

32. Tzika AA, Constantinou C, Bandyopadhaya A, Psychogios N, Lee S, Mindrinos M, Martyn JA, Tompkins RG and Rahme LG: A small volatile bacterial molecule triggers mitochondrial dysfunction in murine skeletal muscle. PLoS One 8: e74528, 2013

33. Astrakas LG, Goljer I, Yasuhara S, Padfield KE, Zhang Q, Gopalan S, Mindrinos MN, Dai G, Yu YM, Martyn JA, et al: Proton NMR spectroscopy shows lipids accumulate in skeletal muscle in response to burn trauma-induced apoptosis. FASEB J 19: 1431-1440, 2005.

34. Padfield KE, Astrakas LG, Zhang Q, Gopalan S, Dai G, Mindrinos MN, Tompkins RG, Rahme LG and Tzika AA: Burn injury causes mitochondrial dysfunction in skeletal muscle. Proc Natl Acad Sci USA 102: 5368-5373, 2005.

35. Morvan D, Demidem A, Papon J and Madelmont JC: Quantitative HRMAS proton total correlation spectroscopy applied to cultured melanoma cells treated by chloroethyl nitrosourea: demonstration of phospholipid metabolism alterations. Magn Reson Med 49: 241-248, 2003

36. Asai A, Sahani N, Kaneki M, Ouchi Y, Martyn JA and Yasuhara SE: Primary role of functional ischemia, quantitative evidence for the two-hit mechanism, and phosphodiesterase-5 inhibitor therapy in mouse muscular dystrophy. PLoS One 2: e806, 2007
37. Hosokawa S, Koseki H, Nagashima M, Maeyama Y, Yomogida K, Mehr C, Rutledge M, Greenfeld H, Kaneki M, Tompkins RG, et al: Title efficacy of phosphodiesterase 5 inhibitor on distant burninduced muscle autophagy, microcirculation, and survival rate. Am J Physiol Endocrinol Metab 304: E922-E933, 2013.

38. Burgmaier G, Schönrock LM, Kuhlmann T, Richter-Landsberg C and Brück W: Association of increased bcl-2 expression with rescue from tumor necrosis factor-alpha-induced cell death in the oligodendrocyte cell line OLN-93. J Neurochem 75: 2270-2276, 2000.

39. Tzifi F, Economopoulou C, Gourgiotis D, Ardavanis A, Papageorgiou S and Scorilas A: The role of BCL2 family of apoptosis regulator proteins in acute and chronic leukemias. Adv Hematol 2012: 524308, 2012

40. Davies L, Spiller D, White MR, Grierson I and Paraoan L: PERP expression stabilizes active p53 via modulation of p53-MDM2 interaction in uveal melanoma cells. Cell Death Dis 2: e136, 2011.

41. Huo J, Xu S and Lam KP: Fas apoptosis inhibitory molecule regulates $\mathrm{T}$ cell receptor-mediated apoptosis of thymocytes by modulating Akt activation and Nur77 expression. J Biol Chem 285: 11827-11835, 2010.

42. Zhou H, Ge Y, Sun L, Ma W, Wu J, Zhang X, Hu X, Eaves CJ, Wu D and Zhao Y: Growth arrest specific 2 is up-regulated in chronic myeloid leukemia cells and required for their growth PLoS One 9: e86195, 2014.

43. Tzika AA, Astrakas LG, Cao H, Mintzopoulos D, Zhang Q, Padfield K, Yu H, Mindrinos MN, Rahme LG and Tompkins RG: Murine intramyocellular lipids quantified by NMR act as metabolic biomarkers in burn trauma. Int J Mol Med 21: 825-832, 2008.

44. Yuzefovych LV, Musiyenko SI, Wilson GL and Rachek LI: Mitochondrial DNA damage and dysfunction, and oxidative stress are associated with endoplasmic reticulum stress, protein degradation and apoptosis in high fat diet-induced insulin resistance mice. PLoS One 8: e54059, 2013.

45. Blankenberg FG: In vivo detection of apoptosis. J Nucl Med 49 (Suppl 2): 81S-95S, 2008.

46. Vayssier-Taussat M, Kreps SE, Adrie C, Dall'Ava J, Christiani D and Polla BS: Mitochondrial membrane potential: a novel biomarker of oxidative environmental stress. Environ Health Perspect 110: 301-305, 2002.

47. Marchi S, Giorgi C, Suski JM, Agnoletto C, Bononi A, Bonora M, De Marchi E, Missiroli S, Patergnani S, Poletti F, et al: Mitochondria-ros crosstalk in the control of cell death and aging. J Signal Transduct 2012: 329635, 2012.

48. Shokolenko I, Venediktova N, Bochkareva A, Wilson GL and Alexeyev MF: Oxidative stress induces degradation of mitochondrial DNA. Nucleic Acids Res 37: 2539-2548, 2009.

49. Blasiak J, Glowacki S, Kauppinen A and Kaarniranta K: Mitochondrial and nuclear DNA damage and repair in agerelated macular degeneration. Int J Mol Sci 14: 2996-3010, 2013.

50. Handschin C and Spiegelman BM: Peroxisome proliferatoractivated receptor gamma coactivator 1 coactivators, energy homeostasis, and metabolism. Endocr Rev 27: 728-735, 2006

51. Lin J, Handschin C and Spiegelman BM: Metabolic control through the PGC-1 family of transcription coactivators. Cell Metab 1: 361-370, 2005.

52. Supinski GS and Callahan LA: Caspase activation contributes to endotoxin-induced diaphragm weakness. J Appl Physiol (1985) 100: 1770-1777, 2006.

53. Tatsumi T, Shiraishi J, Keira N, Akashi K, Mano A, Yamanaka S, Matoba S, Fushiki S, Fliss $\mathrm{H}$ and Nakagawa M: Intracellular ATP is required for mitochondrial apoptotic pathways in isolated hypoxic rat cardiac myocytes. Cardiovasc Res 59: 428-440, 2003

54. Danial NN and Korsmeyer SJ: Cell death: critical control points. Cell 116: 205-219, 2004

55. Szczepaniak LS, Babcock EE, Schick F, Dobbins RL, Garg A, Burns DK, McGarry JD and Stein DT: Measurement of intracellular triglyceride stores by $\mathrm{H}$ spectroscopy: validation in vivo. Am J Physiol 276: E977-E989, 1999.

56. Petersen KF, Befroy D, Dufour S, Dziura J, Ariyan C Rothman DL, DiPietro L, Cline GW and Shulman GI: Mitochondrial dysfunction in the elderly: possible role in insulin resistance. Science 300: 1140-1142, 2003.

57. Petersen KF, Dufour S, Befroy D, Garcia R and Shulman GI: Impaired mitochondrial activity in the insulin-resistant offspring of patients with type 2 diabetes. N Engl J Med 350: 664-671, 2004. 
58. Blankenberg FG, Katsikis PD, Storrs RW, Beaulieu C, Spielman D, Chen JY, Naumovski L and Tait JF: Quantitative analysis of apoptotic cell death using proton nuclear magnetic resonance spectroscopy. Blood 89: 3778-3786, 1997.

59. Boren J and Brindle KM: Apoptosis-induced mitochondrial dysfunction causes cytoplasmic lipid droplet formation. Cell Death Differ 19: 1561-1570, 2012.

60. Hakumäki JM, Poptani H, Sandmair AM, Ylä-Herttuala S and Kauppinen RA: ${ }^{1} \mathrm{H}$ MRS detects polyunsaturated fatty acid accumulation during gene therapy of glioma: implications for the in vivo detection of apoptosis. Nat Med 5: 1323-1327, 1999.

61. Mullen TD and Obeid LM: Ceramide and apoptosis: Exploring the enigmatic connections between sphingolipid metabolism and programmed cell death. Anticancer Agents Med Chem 12: 340-363, 2012.

62. Martinez TN, Chen X, Bandyopadhyay S, Merrill AH and Tansey MG: Ceramide sphingolipid signaling mediates Tumor Necrosis Factor (TNF)-dependent toxicity via caspase signaling in dopaminergic neurons. Mol Neurodegener 7: 45, 2012.

63. Giussani P, Tringali C, Riboni L, Viani P and Venerando B Sphingolipids: key regulators of apoptosis and pivotal players in cancer drug resistance. Int J Mol Sci 15: 4356-4392, 2014.

64. Aureli M, Murdica V, Loberto N, Samarani M, Prinetti A, Bassi R and Sonnino S: Exploring the link between ceramide and ionizing radiation. Glycoconj J 31: 449-459, 2014

65. Jenkins GM: The emerging role for sphingolipids in the eukaryotic heat shock response. Cell Mol Life Sci 60: 701-710, 2003.

66. Van Brocklyn JR and Williams JB: The control of the balance between ceramide and sphingosine-1-phosphate by sphingosine kinase: oxidative stress and the seesaw of cell survival and death. Comp Biochem Physiol B Biochem Mol Biol 163: 26-36, 2012.

67. Yasuhara S, Asai A, Sahani ND and Martyn JA: Mitochondria, endoplasmic reticulum, and alternative pathways of cell death in critical illness. Crit Care Med 35 (Suppl): S488-S495, 2007.

68. Bernardi P and Di Lisa F: The mitochondrial permeability transition pore: molecular nature and role as a target in cardioprotection. J Mol Cell Cardiol 78: 100-106, 2015.

69. Nabben M, Shabalina IG, Moonen-Kornips E, van Beurden D, Cannon B, Schrauwen P, Nedergaard J and Hoeks J: Uncoupled respiration, ROS production, acute lipotoxicity and oxidative damage in isolated skeletal muscle mitochondria from UCP3-ablated mice. Biochim Biophys Acta 1807: 1095-1105, 2011.

70. Reynolds HY, Di Sant'Agnese PA and Zierdt CH: Mucoid Pseudomonas aeruginosa. A sign of cystic fibrosis in young adults with chronic pulmonary disease? JAMA 236: 2190-2192, 1976.

71. Scott-Thomas AJ, Syhre M, Pattemore PK, Epton M, Laing R, Pearson $\mathbf{J}$ and Chambers ST: 2-Aminoacetophenone as a potential breath biomarker for Pseudomonas aeruginosa in the cystic fibrosis lung. BMC Pulm Med 10: 56, 2010.
72. Velsor LW, Kariya C, Kachadourian R and Day BJ: Mitochondrial oxidative stress in the lungs of cystic fibrosis transmembrane conductance regulator protein mutant mice. Am J Respir Cell Mol Biol 35: 579-586, 2006.

73. Divangahi M, Balghi H, Danialou G, Comtois AS, Demoule A, Ernest S, Haston C, Robert R, Hanrahan JW, Radzioch D and Petrof BJ: Lack of CFTR in skeletal muscle predisposes to muscle wasting and diaphragm muscle pump failure in cystic fibrosis mice. PLoS Genet 5: e1000586, 2009.

74. Rottner M, Tual-Chalot S, Mostefai HA, Andriantsitohaina R, Freyssinet JM and Martínez MC: Increased oxidative stress induces apoptosis in human cystic fibrosis cells. PLoS One 6: e24880, 2011.

75. Moylan JS and Reid MB: Oxidative stress, chronic disease, and muscle wasting. Muscle Nerve 35: 411-429, 2007.

76. Schwartz LM: Atrophy and programmed cell death of skeletal muscle. Cell Death Differ 15: 1163-1169, 2008.

77. Aare S, Radell P, Eriksson LI, Akkad H, Chen YW, Hoffman EP and Larsson L: Effects of corticosteroids in the development of limb muscle weakness in a porcine intensive care unit model. Physiol Genomics 45: 312-320, 2013.

78. Xu H, Lam SH, Shen Y and Gong Z: Genome-wide identification of molecular pathways and biomarkers in response to arsenic exposure in zebrafish liver. PLoS One 8: e68737, 2013.

79. Maestre I, Jordán J, Calvo S, Reig JA, Ceña V, Soria B, Prentki M and Roche E: Mitochondrial dysfunction is involved in apoptosis induced by serum withdrawal and fatty acids in the beta-cell line INS-1. Endocrinology 144: 335-345, 2003.

80. Lartigue L and Faustin B: Mitochondria: metabolic regulators of innate immune responses to pathogens and cell stress. Int J Biochem Cell Biol 45: 2052-2056, 2013.

81. Nicolson GL: Mitochondrial dysfunction and chronic disease: treatment with natural supplements. Altern Ther Health Med at5027, 2013

82. Frick CG, Fink H, Gordan ML, Eckel B, Martyn JA and Blobner M: Chronic Escherichia coli infection induces muscle wasting without changing acetylcholine receptor numbers. Intensive Care Med 34: 561-567, 2008.

83. Macallan DC, McNurlan MA, Kurpad AV, de Souza G, Shetty PS, Calder AG and Griffin GE: Whole body protein metabolism in human pulmonary tuberculosis and undernutrition: evidence for anabolic block in tuberculosis. Clin Sci (Lond) 94: 321-331, 1998.

84. Machado AM, Desler C, Bøggild S, Strickertsson JA, Friis-Hansen L, Figueiredo C, Seruca R and Rasmussen LJ: Helicobacter pylori infection affects mitochondrial function and DNA repair, thus, mediating genetic instability in gastric cells. Mech Ageing Dev 134: 460-466, 2013.

85. Morton RE, Hutchings J, Halliday D, Rennie MJ and Wolman SL: Protein metabolism during treatment of chest infection in patients with cystic fibrosis. Am J Clin Nutr 47: 214-219, 1988. 